\title{
Age, geochemistry and petrogenesis of the Charco Rico granitoid complex central Panamá
}

\author{
SCOTT WhatTAM ${ }^{1}$, CARLOS CARRASCO ${ }^{2}$, LISARD \\ TORRÓ ${ }^{3}$, \\ ${ }^{1}$ Department of Geosciences, King Fahd University of \\ Petroleum and Minerals, Dhahran, 31261, Saudi Arabia, \\ sawhatta@gmail.com \\ ${ }^{2}$ Independent Consulting Geologist, Calle Rockefeller, \\ Residencial Palmar View, La Chorrera, Panamá, \\ carlos.c3.2010@gmail.com \\ ${ }^{3}$ Geological Engineering Program, Faculty of Sciences and \\ Engineering, Pontifical Catholic University of Peru \\ (PUCP), Av. Universitaria 1801, San Miguel, Lima-32, \\ Peru, lisardtorro@hotmail.com
}

The Charco Rico prospective comprises a segment of the Sierra de Majé massif in Central Panamá, an intrusive complex constructed about 20 Ma during a lull in volcanic activity at the 75-0 Ma Central American Volcanic Arc system (CAVAS). Charco Rico and related Majé intrusives range from gabbro to granodiorite and represent a medium-K calc-alkaline, metaluminous to weakly peraluminous, relatively unevolved magnesian I-type suite (ASI and A/CNK of 0.7-1.3) akin to Cordilleran batholiths and other slightly older I-type intrusive suites in Panamá. Majé magmas arose from partial melting of a hydrated amphibolite facies, metabasaltic or possibly metatonalitic, LCC-like source with minimal mantle interaction and hornblende as the major fractional phase (e.g., moderate chondrite-normalized MREE depletions). Major residual phases of both hornblende and garnet appear to have been important in controlling the trace element budget of the crustal melts. Zircons of Charco Rico granitoid yield LA-ICP-MS ages of 22-19.5 Ma, in agreement with a 19 Ma zircon age from a previously dated Majé diorite. Collectively, our data is consistent with a model of near complete CAVAS shutdown circa 35-16 Ma followed by slab tear, asthenopheric upwelling and an interval of predominant intrusive activity generated by partial melting of the lowermost, mafic subarc edifice. Results of ongoing and future petrogenetic modelling including $\mathrm{Lu}-\mathrm{Hf}$ isotope systematics of granitoid zircons and documentation of porphyry- $\mathrm{Cu}$ mineralization in Charco Rico and other latest Eocene to lower Miocene intrusives in Panamá will be presented in subsequent contributions. 